\title{
Consumer altruism and risk taking: why do altruistic consumers take more risks?
}

\author{
Sudipta Mukherjee ${ }^{1}$ (D)
}

Received: 8 July 2021 / Accepted: 21 November 2021 / Published online: 2 December 2021

(c) The Author(s), under exclusive licence to Springer-Verlag GmbH Germany, part of Springer Nature 2021

\begin{abstract}
This research studies an interesting and counter-intuitive relationship between consumer altruism and risk taking. While these two constructs have been studied extensively by extant research, there is scant research which has studied the relationship between them - perhaps due to the expectation that individuals who are chronically more altruistic are very different from those who are more risk taking. This research tests this expectation by formally studying the relationship between altruism and risk taking using a mixture of survey-based and experimental methodology. First four studies test the relationship between altruism and risk-taking using survey-based methodology involving some of the most prominent scales for measuring trait altruism and risk taking. The final study investigates the influence of trait altruism on situational social risk taking. Trait altruism and risk taking are found to be significantly positively correlated with each other, with the relationship being the strongest for social risk taking. Further, the relationship is not significant for ethical risk taking. Additionally, it was found that trait optimism could be the underlying cause for the relationship. Further, it was also found that trait altruism was significantly positively correlated with situational social risk taking. Contributions emerge for the literatures on consumer altruism, risk taking, and optimism by filling an important theoretical gap related to the inter-relationships between these three constructs. Additionally, this research has important implications for practice by informing nonprofit organizations about an erstwhile unknown facet of altruistic people - their tendency to take risks. This opens new avenues for nonprofit practitioners to explore when looking to expand the scope and size of their initiatives, and to innovate on their current offerings in a variety of ways. Additionally, it provides insights that can help for-profit marketers to increase participation in their activities.
\end{abstract}

Keywords Consumer altruism $\cdot$ Risk taking $\cdot$ Optimism

Sudipta Mukherjee

mukherjees@xavier.edu

1 Williams College of Business, Xavier University, Cincinnati, OH 45207, USA 


\section{Introduction}

Altruism and risk-taking constructs are well established streams of research - with extensive study on the antecedents and consequences of each of these constructs (Profili et al., 2016; Stark, 1989; To et al., 2018). However, there is scant research which has studied whether there exists any relationship between these two constructs. This is perhaps due to the expectations there would be little or no correspondence between these two constructs because people who are chronically altruistic (widely referred to as the "Good Samaritans") are considered to be very different from those who are chronically risk taking (commonly referred to as the "Dare Devils"). As such, the relationship between these two traits has not been empirically tested.

This research investigates an interesting question: Do people who behave altruistically more often also take more risks? While at a cursory glance, there might appear to be little reason to expect altruistic behavior and risk taking to be connected with each other, detailed analysis of this question, however, reveals an intriguing and counter-intuitive relationship. At the trait level, people who behave altruistically more often are also more likely to take risks than people who behave altruistically less often. Further, at the situational level, individuals who are inherently more altruistic are also more likely to make riskier choices in situations involving risks.

While altruism has been found to be correlated with personality traits such as perspective taking (Batson et al., 1986; Schwartz \& Howard, 1984), and social interest (Crandall \& Harris, 1976), it is possible that interesting but uninvestigated relationships are those with optimism and risk taking. This research hypothesizes and shows that altruism, optimism, and risk taking are positively correlated with each other.

This research makes significant theoretical contributions to a number of important research streams.

First, this research contributes to altruism literature by finding an interesting relationship between altruism and risk taking. Altruism is typically conceptualized as a "positive" trait, while risk taking is considered as a "negative" one. This research shows that such generalizations may not be valid by showing a positive correspondence between the two. Second, while existing research has suggested that altruism is correlated with self-esteem and locus of control (Allen \& Ferrand, 1999; Guagnano, 1995), no research has studied the correlation between altruism and optimism. This research contributes to existing research on altruism by showing that altruism and optimism are correlated with each other. Third, existing research on optimism has found to be correlated with dispositional and situational risk taking (Anderson \& Galinsky, 2006; Kahneman \& Lovallo, 1993). This research contributes to this body of research by identifying specific domains of risk taking that are positively (social and recreational risk taking) and negatively (ethical risk taking) correlated with optimism.

This research has important implications for practice by informing nonprofit organizations about an erstwhile unknown facet of altruistic people - their tendency to take risks. This can have substantial implications for nonprofit practitioners. 
First, this opens new avenues for nonprofit marketers to explore when looking to expand the scope and size of their initiatives by appropriate segmentation and targeting marketing procedures. This research also informs marketers regarding the potential to create advertising communication and in-the-field engagement for charitable initiatives and public interest messages for public policy that connects the two traits of altruism and risk taking. This would help motivate consumers to participate in the altruistic activity by appealing to both of their tendencies. Second, policy makers would benefit from framing messages related to social, recreational, financial, or health/safety domains of risk taking by highlighting any altruistic purposes associated with the risk taking. This can have wide ranging applications for nonprofit practitioners. Third, nonprofit organizations could enhance participation in altruistic tasks by incorporating a token risk-taking opportunity. A prominent example of this is the ALS ice bucket challenge. Fourth, this can provide insights for developing innovative monetary donations schemes. Finally, marketers can use the insights of this research to create advertising and on-the-field engagements for for-profits businesses involving potentially risky activities.

Next, the theoretical bases for the underlying relationship between altruism and risk taking is discussed before presenting the empirical evidence for this relationship.

\section{Literature review}

\subsection{Altruism and optimism}

There are three theoretical bases for expecting a relationship between altruism and optimism. First, extant research commonly categorizes altruism and optimism under the same trait group - both are commonly considered as motivational traits. For example, extant research contends that both, altruism and optimism, are putative motivational protective factors which are involved in mental resilience to environmental stressors (Charney, 2003, 2004) and are genetically influenced, and hence can be grouped together as being similar traits - with similar functions (psychological protection against adverse life experiences) and similar origins (evolutionary development) (Amstadter et al., 2016). Similarly, the actively caring behavior model (Geller, 1995) and its recent adaptation (Kiani et al., 2016) suggests that it would be appropriate to consider altruism and optimism as belonging to the same category of traits. Hence, it is possible that being commonly classified under the same category of traits, trait altruism and trait optimism are indeed proximal in nature and positively correlated with each other.

Second, it is possible that altruism and optimism correspond with each other through a common third trait. Extant research suggests two specific variables that would be most likely to be implicated - trust and cooperativeness. Next, we look at why each of these two specific variables could be the underlying reason why altruism and optimism are connected to each other.

Extant research suggests that both, altruism and optimism, can be potentially correlated with trust (Ben-Ner \& Halldorsson, 2010; Hosmer, 1995; Mansbridge, 
1999). Ben-Ner and Halldorsson (2010) and Mansbridge (1999) contend that altruistic motivations can result in increased likelihood to place trust in others. Further, optimistic expectations of reciprocity can be expected to increase likelihood to trust others (Hosmer, 1995). Thus, with altruism and optimism both being correlated with trust, they can in turn be correlated with each other.

Similarly, significant theoretical research on evolutionary development of human traits has identified altruism and cooperativeness to have developed in close conjunction (Sussman \& Cloninger, 2011). Trait group model of evolutionary development identifies the spread of altruistic and cooperative groups of RNA molecules over selfish and non-cooperative ones as a major transition during the evolutionary process (Michod, 1999; Okasha, 2005; Wilson, 1977), and thus explaining the conjunctive development of the traits, altruism and co-operation. Thus, altruism and cooperativeness can be correlated with each other. Given that there exists substantial research (Engel \& Zhurakhovska, 2016; Gächter et al., 2010; Heinonen et al., 2005; McDonald et al., 1999) on the close connection between cooperativeness and optimism, it is possible that trait altruism and trait optimism will correspond with each other through trait cooperativeness.

Third, extant neuro-scientific research indicates that altruism and optimism potentially share the same neural bases - mesolimbic dopamine pathways which are associated with reward processing. First, the neurotransmitter dopamine is associated with both altruism (Anacker et al., 2013; Bachner-Melman et al., 2005) and optimism (Shah, 2012; Sharot et al., 2011; Sharot et al., 2012). Second, there exists evidence implicating the ventral striatum (which is a target of the dopamine system (Schott et al., 2008) and is involved in reward anticipation (O'Doherty et al., 2004)) in altruism (Harbaugh et al., 2007; Izuma et al., 2010; Moll et al., 2006; Rilling et al., 2004) and optimism (Blair et al., 2013; Hanson et al., 2015; Lefebvre et al., 2017). Thus, perhaps the mesolimbic dopamine system is associated with trait level differences in both altruism and optimism, suggesting possible correspondence between the two traits.

Further, the neuroactive hormone oxytocin has been found to be positively correlated with both - optimism (Kis et al., 2015 (using non-human sample); SaphireBernstein et al., 2011) and altruism (Barraza \& Zak, 2009; Kogan et al., 2011; Poulin et al., 2012; Tost et al., 2010; Zak et al., 2007). Thus, it is possible that as oxytocin is implicated in both optimism and altruism, these two traits are connected at the trait level.

Additionally, physiological research indicates that both altruism and optimism are associated with placebo analgesia. Peciña et al. (2013) found that altruism is positively correlated with placebo analgesia, while Morton et al. (2009) and Geers et al. (2010) found that optimism is positively correlated with an increased expectation for placebo analgesia. Given that altruism and optimism are involved in the physiological phenomena - anticipation of analgesia - they are correlated with each other.

Thus, it is possible that altruism and optimism are positively correlated with each other and that there are neural and physiological bases for this relationship.

Thus, based on the three distinct lines of arguments provided above, it can be expected that altruism will be positively correlated with optimism. Hence, the following hypothesis is posited: 
H1: Trait altruism is positively correlated with trait optimism.

\subsection{Optimism and risk taking}

Further, extant research contends that both dispositional and situational optimism are positively correlated with risk taking (Anderson \& Galinsky, 2006; Åstebro, 2003; DeJoy, 1989; Felton et al., 2003; Kahneman \& Lovallo, 1993). Perhaps, the underlying reason for the positive association between optimism and risk taking is that people who are inherently more optimistic might systematically overestimate their chances of obtaining positive outcomes in risky situations. This might be because being optimistic in nature might lead them to (a) focus on the potential gains in a risky situation and ignore the potential losses as being irrelevant, and/or (b) over-estimate the likelihood of a gain from the risky outcome and under-estimate the likelihood of a loss. In either case, it can be expected that higher the trait optimism higher would be trait risk taking.

Further, the relationship between optimism and risk taking can be expected to vary across different types of risk taking. Specifically, Weber et al. (2002) identify five distinct types of trait risk taking: social, recreational, financial, health/safety, and ethical. Out of these five types of risk taking, trait optimism can be expected to be positively correlated with social, recreational, financial, and health/safety risk taking, but not with ethical risk taking. This is because optimism is a plausible antecedent to increased risk taking in endeavors involving social, recreational, financial, health/safety risks, but not those compromising ethical life values of an individual, which are likely to influence ethical risk-taking tendencies more than motivational trait such as optimism. In fact, extant research suggests a positive correlation between ethicality and optimism (De Hoogh \& Den Hartog, 2008; Grobler \& Joubert, 2020; Hough et al., 2020). If anything, this would suggest that trait optimism and ethical risk taking should be negatively correlated with each other. Thus, trait optimism should be positively correlated with trait social, recreational, financial, and health/safety risk taking, but not with ethical risk taking.

Further, the relationship between trait optimism and trait risk taking can be expected to be the strongest in the case of social risk taking. This is because optimism has been extensively related with the extraversion dimension of the big five trait inventory (Brebner et al., 1995; Marshall et al., 1992; Sharpe et al., 2011), and is considered as the defining characteristic of extraversion (Williams, 1992), which in turn is predominantly related to confidence in interpersonal interactions (Klein, 2009; Lee \& Ashton, 2004; Markey \& Markey, 2006). Given that social risk taking is predominantly characterized by confidence in interpersonal interactions (Blais \& Weber, 2006; Weber et al., 2002), optimism can be expected to be strongly correlated with social risk taking, with the influence being solely attributed to confidence in interpersonal interactions. As such, a clear path (e.g., through confidence in interpersonal interactions in the case of social risk taking) can't be argued for the influence of optimism on recreational, financial, or health/safety risk taking, hence, it can be predicted that the strength of the positive relationship between optimism and risk taking will be the strongest in the case of social risk taking. 
Thus, the following can be hypothesized:

$\mathrm{H} 2$ : Trait optimism is positively correlated with trait risk taking.

$\mathrm{H} 2$ (a): The positive correlation between trait optimism and risk taking is the strongest in the domain of social risk taking

H2 (b): Trait optimism is not positively correlated with ethical risk taking

\subsection{Altruism and trait risk taking}

Considering the proposed positive relationship between altruism and optimism, it can be expected that altruism and risk taking would be positively correlated with each other.

Thus, combining $\mathrm{H} 1$ and $\mathrm{H} 2$ :

H3: Trait altruism is positively correlated with trait risk taking

H3 (a): The positive correlation between trait altruism and risk taking is the strongest in the domain of social risk taking

H3 (b): Trait altruism is not positively correlated with ethical risk taking

While this research focuses on optimism as the underlying connection between trait altruism and trait risk taking, it is possible that there can be three other explanatory reasons: self-esteem, locus-of-control, and belief-in-karma. First, altruism has been found to be correlated with self-esteem and locus of control (Allen \& Ferrand, 1999; Guagnano, 1995), which in turn have been found to correspond with risk-taking (Baron, 1968; McElroy et al., 2007; Rothbaum et al., 1982). Thus, selfesteem and locus of control are potential alternative reasons why trait altruism and trait risk taking are correlated with each other. Second, another potential alternative mechanism by which trait altruism and trait risk taking are connected to each other could be belief in karma (Kopalle et al., 2010). Belief in karma is the belief that good deeds are rewarded and bad deeds are punished (White, 2017). That is, someone with strong karmic beliefs would believe that performing altruistic activities in service of others bestows supernatural benefits (White \& Norenzayan, 2019) such as invulnerability to losses and imperviousness to the potential negative outcomes of risk taking. This can translate into higher risk taking amongst individuals with stronger karmic beliefs. Extant research has shown mixed results with respect to the relationship between belief in karma and risk taking, such that strong karmic beliefs have been shown to translate into both lower (Chamratrithirong et al., 2010) and higher risk taking (Liu et al., 2019). Now, individuals who are inherently more likely to perform altruistic actions might also be more likely to believe that such activities provide karmic benefits (Kulow \& Kramer, 2016) and thus possibly take more risks. Thus, belief in karma can also could be the underlying reason for the relationship between trait altruism and trait risk taking.

Additionally, it can be expected that altruism and risk taking be correlated not only at the trait level, but also at the situational level. Amongst the five different types of risk taking, this research specifically focuses on social risk taking as: (a) 
the correlation between trait altruism and trait risk taking should be the strongest for social risk-taking domains, (b) social risks are pervasive in interpersonal interactions, and are commonly encountered while making consumption choices. In fact, one way to interpret consumer decisions involving signaling to others is that involving between a potentially risky option, which are more in alignment with one's own preferences rather than established societal norms and can possibly offend others, and a safe option, which is socially more acceptable but not reflecting own preferences. Hence, it would be interesting to test whether trait altruism, an ostensibly unrelated trait, can predict the likelihood to take risks in social situations.

Basis the hypothesized positive relationship between trait altruism and trait optimism, it is possible that consumers who are inherently altruistic in nature would also be more likely to be systematically more optimistic about their chances in risky situations. Thus, consumers who are higher in trait altruism would be more likely to take social risks than those who are lower in trait altruism. Thus, the following hypothesis is posited:

Thus, the following hypothesis can be posited:

H4: Trait altruism will be positively correlated with likelihood to take social risks

Next, studies 1(a), (b), (c), and 2 are presented which test the above hypotheses.

\section{Methodology}

\subsection{Studies 1A, B, C, \& D}

\subsubsection{Design and procedure}

All four studies study employed a correlational survey-based method in which respondents were presented with scale-based measures. While study 1 A involved one hundred and forty-five undergraduate students $\left(M_{\text {age }}=20.95,72\right.$ female respondents), studies 1B, C, \& D involved Amazon MTurk respondents (1B: $N=191, M_{\text {age }}=37.33,92$ female respondents; $1 \mathrm{C}: N=208, M_{\text {age }}=37.22$, 95 female respondents; 1D: $N=206, M_{\text {age }}=37.08,143$ female respondents). Each of the four studies measured altruism, risk taking, optimism, and locus of control. Altruism was measured using a 21-item self-reported measure $(\alpha=0.90)$ that was based on Self-Reported Altruism Scale (SRA) (Rushton et al., 1981; Appendix 1). 30-item Domain Specific Risk Taking (DOSPERT) scale $(\alpha=0.91)$ (Weber et al., 2002; Appendix 2) was utilized to test trait risk taking. Optimism was tested using 6 items $(\alpha=0.93)$ from the Life Orientation Test - Revised (LOT-R) (Scheier et al., 1994; Appendix 3). Locus of control was tested using 6 items $(\alpha=0.72)$ from Rotter's locus of control scale (Rotter, 1966; Appendix 4).

In addition, self-esteem was measured only in study $1 \mathrm{~A}$ and belief in karma were measured in study 1B, C, \& D. Self-esteem was measured using 10 items $(\alpha=0.88)$ from Rosenberg self-esteem scale (Rosenberg, 1965; Appendix 5). Trait belief in karma was tested using 6 item scale $(\alpha=0.82)$ the items of which are presented in 
Appendix 6. In addition, respondents also answered demographic questions regarding their age and gender.

\subsubsection{Results}

Table 1 presents details of the correlation coefficients between altruism and the five domains of risk taking for each of the four studies.

As predicted, combining the data from all four studies shows that the relationship between altruism and risk taking is the strongest for social risk taking $(\beta=0.38$, $p<.001$ ) (supporting H3(a)). Further, as hypothesized, this relationship is not significant for ethical risk taking $(\beta=0.03, p=.39)$ (supporting $\mathrm{H} 3(\mathrm{~b})$ ).

Further, while bivariate correlation between altruism and optimism is significant $(\beta=0.25, p<.001)$ (supporting H1) (Table 2 ), and optimism is not significantly correlated with overall risk taking $(\beta=0.024, p=.51)$ (Table 3). Optimism is significantly positively correlated with social $(\beta=0.345, p<.001)$ and recreational risk taking $(\beta=0.127, p<.001)$, and significantly negatively correlated with health/safety risk taking $(\beta=-0.076, p=-.037)$ and ethical risk taking $(\beta=-0.252$, $p<.001)$. Further, optimism is not correlated with financial risk taking $(\beta=0.034$, $p=.35)$. Further, optimism is significantly negatively correlated with health/safety risk taking $(\beta=-0.076, p=.037)$ and ethical risk taking $(\beta=-0.25, p<.001)$. While this provides partial support for $\mathrm{H} 2$, it does provide support for $\mathrm{H} 2$ (a) and $\mathrm{H} 2$ (b).

Finally, while altruism is significantly positively correlated with locus of control $(\beta=0.094, p=.01)$ and belief in karma $(\beta=0.24, p<.001)$ (Table 2$)$, these in turn were significantly positively correlated with social risk taking: locus of control $(\beta=0.12, \mathrm{p}<.001)$ and belief in karma $(\beta=0.14, \mathrm{p}=.001)$ (Table 4). Also, interestingly, altruism was significantly negatively correlated with self-esteem (reverseitemed scale) $(\beta=0.16, p=.052)$.

\subsection{Study 2}

\subsubsection{Design and procedure}

One hundred and eighteen undergraduate students $\left(M_{\text {age }}=20.76 ; 67\right.$ female respondents) took part in this study in exchange for course credit. This study utilized a procedure similar to the previous studies. However, trait risk taking was measured using a different measure involving 7 items $(\alpha=0.80)$ from the risk propensity scale (Meertens \& Lion, 2008; Appendix 7). Further, in addition to the trait risk taking measure, this study also included a situational social risk-taking measure adapted from Mandel (2003) (Appendix 8).

\subsubsection{Results}

Bivariate correlational analysis revealed that trait altruism is significantly positively correlated with trait risk taking $(\beta=0.26, p=.004)$. Additionally, altruism also 


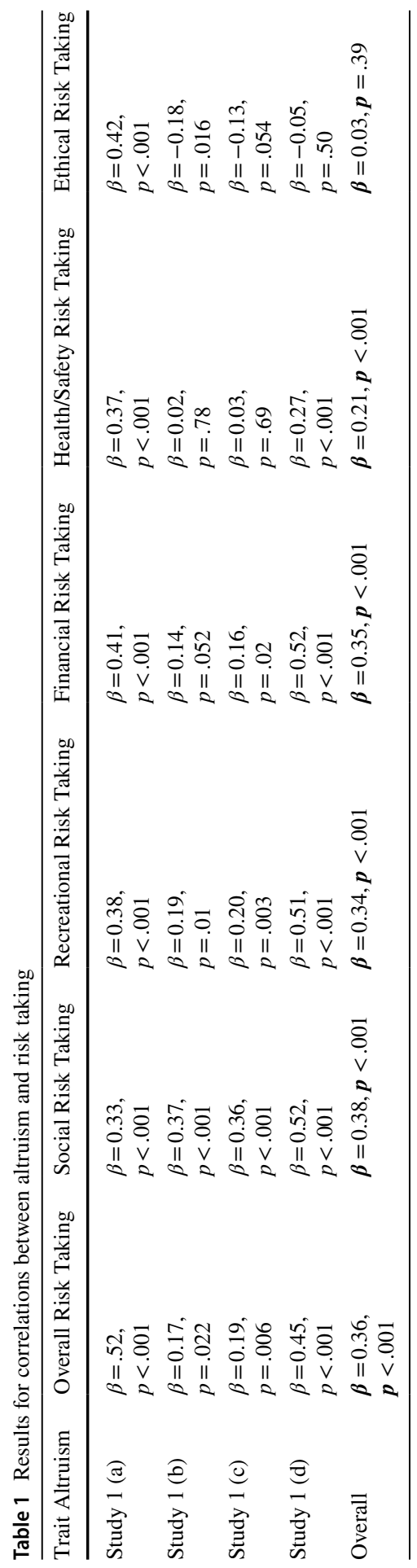


Table 2 Results for correlations between altruism and optimism

\begin{tabular}{lllll}
\hline Trait Altruism & Optimism & Self-Esteem & Locus of Control & Belief in Karma \\
\hline Study 1 (a) & $\beta=-0.05$, & $\beta=0.16$, & $\beta=-0.11$, & NA \\
& $p=.53$ & $p=.052$ & $p=.21$ & \\
Study 1 (b) & $\beta=0.29$, & NA & $\beta=0.16$, & $\beta=0.35$, \\
& $p<.001$ & & $p=.028$ & $p<.001$ \\
Study 1 (c) & $\beta=0.27$, & & $\beta=0.18$, & $\beta=0.32$, \\
& $p<.001$ & & $p=.011$ & $p<.001$ \\
Study 1 (d) & $\beta=0.65$, & $\beta=0.06$, & $\beta=0.17$, \\
& $p<.001$ & $p=.40$ & $p=.013$ \\
Overall & $\boldsymbol{\beta}=0.25$, & $\boldsymbol{\beta}=0.094$, & $\boldsymbol{\beta}=0.24$, \\
& $\boldsymbol{p}<.001$ & $\boldsymbol{p}=.01$ & $\boldsymbol{p}<.001$ \\
\hline
\end{tabular}

significantly predicted the likelihood to choose the riskier option in the situational social risk-taking measure $(\beta=0.25, p=.006)$.

\section{Summary}

This research studies an interesting and counter-intuitive relationship between altruism and risk taking. Typically, risk taking is considered as a negative trait and individuals with higher propensity to perform altruistic actions, the good Samaritans of this world, would not be commonly associated with risky actions. This research however finds evidence against this common belief and shows that altruism and risk taking are indeed positively connected. At the trait level, it is found that trait altruism and risk taking are positively correlated, with the effect being the strongest for social risk taking. Trait optimism is found to be positively correlated with both altruism and social risk taking. Further, the alternative potential mechanisms, locus of control and belief in karma, were found to not be correlated with risk taking.

Further, in order to test the robustness of the findings, this research replicates the findings across student and general populations and different operationalizations of risk taking. Four studies are used in the first stage to test the replicability of the focal findings related to trait altruism and trait risk taking. Additionally, one study was conducted in the next stage to show the generalizability of the findings by operationalizing a different measure of trait risk taking, in addition to studying the effect in the area of situational social risk taking.

\subsection{Theoretical contributions}

This research makes a number of important contributions. First, it finds a novel relationship between two dispositional traits, altruism and risk taking, both of which are connected to several important areas within marketing and public policy. Given, that altruism and risk taking are typically conceptualized as "positive" and "negative" traits respectively, this research finds an interesting and counter-intuitive relationship between the two. Second, it informs existing research of the correspondence 


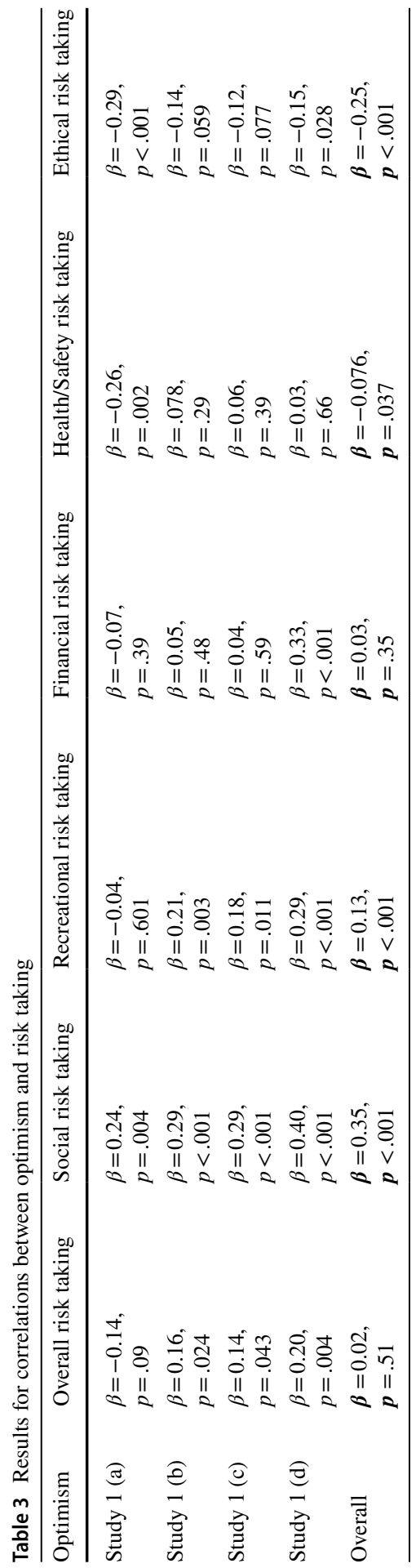




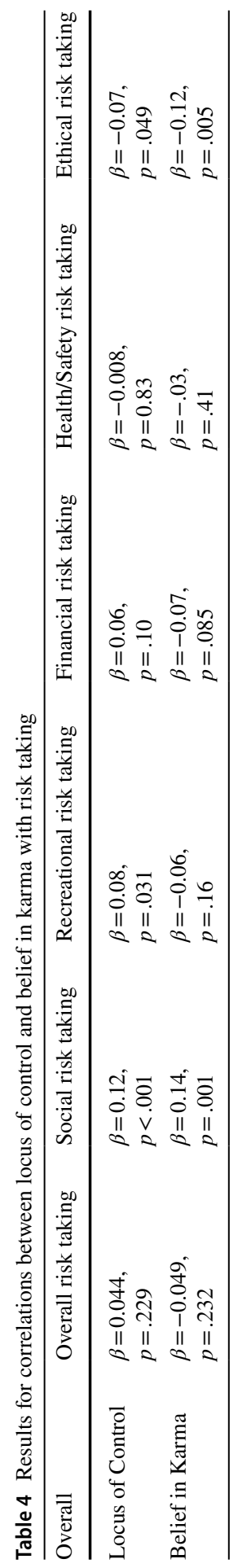


between altruism and optimism - something that has not yet been shown before. While existing research has suggested that altruism is correlated with self-esteem and locus of control (Allen \& Ferrand, 1999; Guagnano, 1995), no research has studied the correlation between altruism and optimism. This relationship could indicate that altruistic people are also more optimistic because either (a) behaving altruistically increases optimism, or (b) optimistic people are more likely to behave altruistically. Third, existing research on optimism has found to be correlated with dispositional and situational risk taking (Anderson \& Galinsky, 2006; Kahneman \& Lovallo, 1993). This research contributes to this body of research by identifying specific domains of risk taking that are positively (social and recreational risk taking) and negatively (ethical risk taking) correlated with optimism.

\subsection{Practical implications}

This research has important implications for practice by informing nonprofit organizations about an erstwhile unknown facet of altruistic people - their tendency to take risks. This can have substantial implications for nonprofit practitioners.

First, this opens new avenues for nonprofit marketers to explore when looking to expand the scope and size of their initiatives by appropriate segmentation and targeting procedures. Nonprofits segment the market on psychographic variables to better understand potential donors (Randle \& Dolnicar, 2009; Rupp et al., 2014). Additionally, emphasis is placed on using motivational values (Thyne, 2001) and personality types (Lim et al., 2020) as a basis for targeting donation appeals. Insights from this research can help nonprofit practitioners' better segment and target their potential donors by providing a deeper understanding about their altruistic and risk-taking propensities.

Second, policy makers would benefit from framing messages related to social, recreational, financial, or health/safety domains of risk taking by highlighting any altruistic purposes associated with the risk taking. This can have wide ranging applications. For example, encouraging youth who do not use drugs to take the socially risky initiative to discourage their peers who use drugs might be easier when such an initiative is framed as an altruistic task. Also, people may be more willing to take the potential social risk of sharing cause-related marketing messages on their social media if they are aware about the altruistic purpose of such messages. Similarly, somewhat akin to the support for bonds sold by various governments during world war II (Frey \& Kucher, 1999; Gilson et al., 2013), consumers may be more willing to support a risky financial asset offered by the government when the investment is highlighted as an altruistic effort. Also, volunteering for military services which are typically considered to involve health/safety risk could be encouraged when the altruistic aspects of such services are highlighted. Further, volunteering for service organizations such as Peace Corps or Voluntary Service Overseas (VSO) could be increased if both the altruistic purposes and potential risk-taking opportunities are emphasized. For example, the potential risks of serving in COVID-19 affected areas along with the altruistic purpose could both be motivating for altruistic people to join VSO to serve. In addition, nonprofit education ventures such as Teach First or 
Teach for America could increase the likelihood that people may take the risk of taking a semester off if the altruistic benefits are emphasized.

Third, nonprofit organizations could enhance participation in altruistic tasks by incorporating a token risk-taking opportunity. A prominent example of this is the ALS ice bucket challenge which involved the socially (and health/safety wise) risky activity of capturing a video of oneself being dunked by an ice-cold bucket of water (Pressgrove et al., 2018; Vaidya, 2014). Future such initiatives which frame an altruistic ask as that involving a risky task could benefit from increased participation levels. For example, participation in sweepstakes/lotteries which support a cause would be greater if the altruistic purposes and the token financial risk involved in participation are highlighted.

Fourth, nonprofit practitioners can develop innovative monetary donation schemes using the insights presented in this research. Given that trait altruism is found to be significantly correlated with trait financial risk taking, it is possible that nonprofit organizations could offer monetary donation schemes that involve a certain portion of the donation amount to be invested in financial instruments such as equities and mutual funds, which are traditionally perceived as "risky-but-rewarding" financial instruments (Aren \& Zengin, 2016). Additionally, consumer financial investment apps such as Robinhood could increase consumer participation by offering consumers an opportunity to allocate a certain portion of their earnings to be donated to nonprofits of their choice. Interestingly, Robinhood currently states its mission as "to democratize finance for all" ("Our Mission", , 2021) - an altruistic promise of inclusion that benefits all members of society (Johnson et al., 2019). It is possible that more such altruistic purposes adopted by financial investment companies could increase consumer tendency to make more risky investments while using their services.

Finally, this research also informs marketers regarding the potential to create advertising communication and on-the-field engagement for for-profit businesses involving potentially risky activities. For example, marketers of risky recreational activities, such as bungee jumping or white-water rafting, could increase the likelihood of participating in those sports when a plausible altruistic purpose for participating in the sport is emphasized.

\subsection{Future research directions}

First, follow up research needs to test whether situational acts of altruism result in increased subsequent risk taking. While this research identifies the relationship between trait altruism and trait (and) situational social risk taking, future research needs to test whether situational acts of altruism results in increased subsequent social risk taking. Based on the "warm glow" effect (Andreoni, 1990; Harbaugh, 1998), it can be predicted that behaving altruistically should enhance optimism, and thus result in increased subsequent social risk taking. Future research needs to test this prediction.

Additionally, it would also be interesting to test whether altruistic motivations increase likelihood to take risks. That is, future research needs to test whether a 
task involving risk is more likely to be undertaken when the underlying motivation is altruistic vs. self-benefit driven. It is possible that an altruistic motivation is accompanied with a more optimistic estimation of one's chances of succeeding in a risky task, thereby enhancing the propensity to undertake the risky task, and that the same is not the case for self-benefit motivation. If true, this could be one way of understanding why fire-fighters routinely risk their lives.

Second, future research needs to empirically test the reasons why altruism and optimism are correlated with each other. While this research presents several theoretical arguments for this relationship, there exists no empirical evidence of the underlying process by which these two motivational variables correspond with each other. Specifically, this research contends that altruism and optimism potentially correspond with each other (a) through the path variables of trust and cooperativeness, (b) due to underlying neural and physiological mechanisms. The underlying mechanism for the relationship between altruism and optimism indeed needs to be empirically investigated. Further, future research also needs to test whether there is a causal relationship between altruism and optimism.

Third, this research finds that optimism, locus of control, and belief in karma are all correlated with both altruism and social risk taking. Future research needs to explore which of the these three is more implicated in the relationship between altruism and social risk taking. It is more likely that behaving altruistically can increase situational optimism ("warm glow" effect; Andreoni, 1990; Harbaugh, 1998) as compared to experiencing an increased locus of control. Thus, at the situational level, the correspondence between altruism and social risk taking would be more likely to be mediated by optimism as compared to locus of control. However, based on belief in karma research (Kopalle et al., 2010; Kulow \& Kramer, 2016; White, 2017; White \& Norenzayan, 2019), it is quite likely that behaving altruistically can generate beliefs about accruing positive karmic reactions, and this in turn can license "spending" of this good karma by indulging in subsequent risk taking. Future research should systematically test which out of the two, optimism and belief in karma, mediates the influence of altruism on risk taking. It is possible that they operate in parallel. However, future research needs to test this possibility.

Finally, research also needs to explore the possibility that certain risky choices may be more likely to be undertaken when they are framed from an altruistic perspective. For example, certain consumption choices that are perceived involving social risks - such as being the first in the neighborhood to install roof-top solar panels - could be more likely to be performed when framed as an altruistic (proenvironmental choice) rather than a purely materialistic (cost-saving) decision.

\section{Appendix 1}

\section{Self-Reported Altruism Scale}

Using the following scale, please select the category that conforms to the frequency with which you have carried out the following acts. 
1. I have helped push a stranger's car that was broken down or out of gas.

2. I have given directions to a stranger.

3. I have made change for a stranger.

4. I have given money to a charity.

5. I have given money to a stranger who needed it (or asked me for it).

6. I have donated goods or clothes to a charity.

7. I have done volunteer work for a charity.

8. I have donated blood.

9. I have helped carry a stranger's belongings (books, parcels, etc).

10. I have delayed an elevator and held the door open for a stranger.

11. I have allowed someone to go ahead of me in a lineup (in the supermarket, at a copy.

12. machine, at a fast-food restaurant).

13. I have given a stranger a lift in my car

14. I have pointed out a clerk's error (in a bank, at the supermarket) in undercharging me.

15. for an item.

16. I have let a neighbor whom I didn't know too well borrow an item of some value to

17. me (e.g. a dish, tools, etc.).

18. I have bought 'charity' holiday cards deliberately because I knew it was a good cause.

19. I have helped a classmate who I did not know that well with an assignment when my.

20. knowledge was greater than his or hers.

21. I have, before being asked, voluntarily looked after a neighbor's pets or children

22. without being paid for it.

23. I have offered to help a handicapped or elderly stranger across a street.

24. I have offered my seat on a bus or train to a stranger who was standing.

25. I have helped an acquaintance to move households.

26. I have helped a stranger looking for an address.

\section{Appendix 2}

\section{Domain Specific Risk Taking Scale}

For each of the following statements, please indicate the likelihood that you would engage in the described activity or behavior if you were to find yourself in that situation. Provide a rating from Extremely Unlikely (1) to Extremely Likely (7), using the following scale:

1. Admitting that your tastes are different from those of a friend. (S). 
2. Going camping in the wilderness. (R).

3. Betting a day's income at the horse races. (F/G).

4. Investing $10 \%$ of your annual income in a moderate growth diversified fund. $(\mathrm{F} / \mathrm{I})$.

5. Drinking heavily at a social function. (H/S).

6. Taking some questionable deductions on your income tax return. (E).

7. Disagreeing with an authority figure on a major issue. (S).

8. Betting a day's income at a high-stake poker game. $(\mathrm{F} / \mathrm{G})$.

9. Having an affair with a married man/woman. (E).

10. Passing off somebody else's work as your own. (E).

11. Going down a ski run that is beyond your ability. (R).

12. Investing $5 \%$ of your annual income in a very speculative stock. (F/I).

13. Going whitewater rafting at high water in the spring. (R).

14. Betting a day's income on the outcome of a sporting event $(\mathrm{F} / \mathrm{G})$.

15. Engaging in unprotected sex. (H/S).

16. Revealing a friend's secret to someone else. (E).

17. Driving a car without wearing a seat belt. $(\mathrm{H} / \mathrm{S})$.

18. Investing $10 \%$ of your annual income in a new business venture. (F/I).

19. Taking a skydiving class. (R).

20. Riding a motorcycle without a helmet. (H/S).

21. Choosing a career that you truly enjoy over a more secure one. (S).

22. Speaking your mind about an unpopular issue in a meeting at work. (S).

23. Sunbathing without sunscreen. (H/S).

24. Bungee jumping off a tall bridge. (R).

25. Piloting a small plane. (R).

26. Walking home alone at night in an unsafe area of town. (H/S).

27. Moving to a city far away from your extended family. (S).

28. Starting a new career in your mid-thirties. (S).

29. Leaving your young children alone at home while running an errand. (E).

30. Not returning a wallet you found that contains $\$ 200$. (E).

Note. $\mathrm{E}=$ Ethical, $\mathrm{F}=$ Financial, $\mathrm{H} / \mathrm{S}=$ Health/Safety, $\mathrm{R}=$ Recreational, and $\mathrm{S}=$ Social.

\section{Appendix 3}

\section{Life-Orientation/Optimism Scale}

On a scale from strongly disagree (1) to strongly agree (7), please indicate the extent to which you agree with each of the following statements:

1. In uncertain times, I usually expect the best.

2. If something can go wrong for me, it will. (R).

3. I'm always optimistic about my future.

4. I hardly ever expect things to go my way. (R). 
5. I rarely count on good things happening to me. (R).

6. Overall, I expect more good things to happen to me than bad.

\section{Appendix 4}

\section{Locus of Control Scale}

On a scale from strongly disagree (1) to strongly agree (7), please indicate the extent to which you agree with each of the following statements:

1. Becoming a success is a matter of hard work.

2. Becoming a success has little or nothing to do with luck.

3. Getting what I want has little or nothing to do with luck.

4. I feel that I have little influence over things that happen to me. (R).

5. What happens to me is my own doing.

6. Most people don't realize the extent to which their lives are controlled by chance happenings. $(\mathrm{R})$.

\section{Appendix 5}

\section{Rosenberg Self Esteem Scale}

On a scale from strongly disagree (1) to strongly agree (7), please indicate the extent to which you agree with each of the following statements:

1. On the whole, I am satisfied with myself.

2. At times I think I am no good at all. (R).

3. I feel that I have a number of good qualities.

4. I am able to do things as well as most other people.

5. I feel I do not have much to be proud of. (R).

6. I certainly feel useless at times. (R).

7. I feel that I'm a person of worth, at least on an equal plane with others.

8. I wish I could have more respect for myself. (R).

9. All in all, I am inclined to feel that I am a failure. (R).

10. I take a positive attitude toward myself.

\section{Appendix 6}

\section{Belief in Karma Scale}

On a scale from strongly disagree (1) to strongly agree (7), please indicate the extent to which you agree with each of the following statements:

1. Performing good deeds in the present lead to good outcomes in the future.

2. Bad actions in the present lead to bad outcomes in the future. 
3. When someone does the right thing, they will eventually be rewarded.

4. Being moral or immoral in the present does not affect what happens later in life. (R)

5. Give and you shall receive.

6. I don't believe in karma. (R)

\section{Appendix 7}

\section{Risk Propensity Scale}

On a scale from strongly disagree (1) to strongly agree (7), please indicate the extent to which you agree with each of the following statements:

1. Safety first. (R)

2. I do not take risks with my health. (R)

3. I prefer to avoid risks. (R)

4. I take risks regularly.

5. I really dislike not knowing what is going to happen. (R)

6. I usually view risks as a challenge.

7. I view myself as a ... (risk avoider 1) (risk taker 7)

\section{Appendix 8}

\section{Situational Social Risk Taking Measure}

Choice between truth and dare in a game of truth or dare

Imagine that you are attending a picnic with friends. During the picnic, everyone decides on playing the game of truth or dare - where everyone has to take turns to either speak a truth about themselves or dare to do any activity that the group decides for them. While playing the game, your turn comes and there are two choices: Choose Truth or Choose Dare.

What would you choose?

\section{References}

Allen, J. B., \& Ferrand, J. L. (1999). Environmental locus of control, sympathy, and proenvironmental behavior: A test of Geller's actively caring hypothesis. Environment and Behavior, 31(3), 338-353.

Amstadter, A. B., Moscati, A., Maes, H. H., Myers, J. M., \& Kendler, K. S. (2016). Personality, cognitive/psychological traits and psychiatric resilience: A multivariate twin study. Personality and Individual Differences, 91, 74-79.

Anacker, K., Enge, S., Reif, A., Lesch, K. P., \& Strobel, A. (2013). Dopamine D4 receptor gene variation impacts self-reported altruism. Molecular Psychiatry, 18(4), 402. 
Anderson, C., \& Galinsky, A. D. (2006). Power, optimism, and risk-taking. European Journal of Social Psychology, 36(4), 511-536.

Andreoni, J. (1990). Impure altruism and donations to public goods: A theory of warm-glow giving. The Economic Journal, 100(401), 464-477.

Aren, S., \& Zengin, A. N. (2016). Influence of financial literacy and risk perception on choice of investment. Procedia-Social and Behavioral Sciences, 235, 656-663.

Åstebro, T. (2003). The return to independent invention: Evidence of unrealistic optimism, risk seeking or skewness loving? The Economic Journal, 113(484), 226-239.

Bachner-Melman, R., Gritsenko, I., Nemanov, L., Zohar, A. H., Dina, C., \& Ebstein, R. P. (2005). Dopaminergic polymorphisms associated with self-report measures of human altruism: A fresh phenotype for the dopamine D4 receptor. Molecular Psychiatry, 10(4), 333.

Baron, R. A. (1968). Authoritarianism, locus of control, and risk taking. The Journal of Psychology, $68(1), 141-143$

Barraza, J. A., \& Zak, P. J. (2009). Empathy toward strangers triggers oxytocin release and subsequent generosity. Annals of the New York Academy of Sciences, 1167(1), 182-189.

Batson, C. D., Bolen, M. H., Cross, J. A., \& Neuringer-Benefiel, H. E. (1986). Where is the altruism in the altruistic personality? Journal of Personality and Social Psychology, 50(1), 212.

Ben-Ner, A., \& Halldorsson, F. (2010). Trusting and trustworthiness: What are they, how to measure them, and what affects them. Journal of Economic Psychology, 31(1), 64-79.

Blair, K. S., Otero, M., Teng, C., Jacobs, M., Odenheimer, S., Pine, D. S., \& Blair, R. J. R. (2013). Dissociable roles of ventromedial prefrontal cortex (vmPFC) and rostral anterior cingulate cortex (rACC) in value representation and optimistic bias. NeuroImage, 78, 103-110.

Blais, A. R., \& Weber, E. U. (2006). A domain-specific risk-taking (DOSPERT) scale for adult populations.

Brebner, J., Donaldson, J., Kirby, N., \& Ward, L. (1995). Relationships between happiness and personality. Personality and Individual Differences, 19(2), 251-258.

Chamratrithirong, A., Miller, B. A., Byrnes, H. F., Rhucharoenpornpanich, O., Cupp, P. K., Rosati, M. J., et al. (2010). Spirituality within the family and the prevention of health risk behavior among adolescents in Bangkok, Thailand. Social Science \& Medicine, 71(10), 1855-1863.

Charney, D. S. (2003). The psychobiology of resilience and vulnerability to anxiety disorders: Implications for prevention and treatment. Dialogues in Clinical Neuroscience, 5(3), 207.

Charney, D. S. (2004). Psychobiological mechanisms of resilience and vulnerability: Implications for successful adaptation to extreme stress. American Journal of Psychiatry, 161(2), 195-216.

Crandall, J. E., \& Harris, M. D. (1976). Social interest, cooperation, and altruism. Journal of Individual Psychology.

De Hoogh, A. H., \& Den Hartog, D. N. (2008). Ethical and despotic leadership, relationships with leader's social responsibility, top management team effectiveness and subordinates' optimism: A multimethod study. The Leadership Quarterly, 19(3), 297-311.

DeJoy, D. M. (1989). The optimism bias and traffic accident risk perception. Accident Analysis \& Prevention, 21(4), 333-340.

Engel, C., \& Zhurakhovska, L. (2016). When is the risk of cooperation worth taking? The prisoner's dilemma as a game of multiple motives. Applied Economics Letters, 23(16), 1157-1161.

Felton, J., Gibson, B., \& Sanbonmatsu, D. M. (2003). Preference for risk in investing as a function of trait optimism and gender. The Journal of Behavioral Finance, 4(1), 33-40.

Frey, B. S., \& Kucher, M. (1999). Wars and markets: How bond values reflect world war II.

Gächter, S., Nosenzo, D., Renner, E., \& Sefton, M. (2010). Sequential vs. simultaneous contributions to public goods: Experimental evidence. Journal of Public Economics, 94(7-8), 515-522.

Geers, A. L., Wellman, J. A., Fowler, S. L., Helfer, S. G., \& France, C. R. (2010). Dispositional optimism predicts placebo analgesia. The Journal of Pain, 11(11), 1165-1171.

Geller, E. S. (1995). Actively caring for the environment: An integration of behaviorism and humanism. Environment and Behavior, 27(2), 184-195.

Gilson, M., Oosterlinck, K., \& Ukhov, A. D. (2013). Risk aversion during world war II: Evidence from Belgian lottery bond prices.

Grobler, A., \& Joubert, Y. T. (2020). The relationship between hope and optimism, ethical leadership and person-organisation fit. South African Journal of Economic and Management Sciences, 23(1), 1-11.

Guagnano, G. A. (1995). Locus of control, altruism and agentic disposition. Population and Environment, 17(1), 63-77. 
Hanson, J. L., Hariri, A. R., \& Williamson, D. E. (2015). Blunted ventral striatum development in adolescence reflects emotional neglect and predicts depressive symptoms. Biological Psychiatry, 78(9), 598-605.

Harbaugh, W. T. (1998). What do donations buy?: A model of philanthropy based on prestige and warm glow. Journal of Public Economics, 67(2), 269-284.

Harbaugh, W. T., , Mayr, U., \& Burghart, D. R. (2007). Neural responses to taxation and voluntary giving reveal motives for charitable donations. Science, 316(5831), 1622-1625.

Heinonen, K., Räikkönen, K., \& Keltikangas-Järvinen, L. (2005). Dispositional optimism: Development over 21 years from the perspectives of perceived temperament and mothering. Personality and Individual Differences, 38(2), 425-435.

Hosmer, L. T. (1995). Trust: The connecting link between organizational theory and philosophical ethics. Academy of Management Review, 20(2), 379-403.

Hough, C., Sumlin, C., \& Green, K. W. (2020). Impact of ethics, trust, and optimism on performance. Management Research Review.

Izuma, K., Saito, D. N., \& Sadato, N. (2010). Processing of the incentive for social approval in the ventral striatum during charitable donation. Journal of Cognitive Neuroscience, 22(4), 621-631.

Johnson, K., Pasquale, F., \& Chapman, J. (2019). Artificial intelligence, machine learning, and bias in finance: Toward responsible innovation. Fordham L. Rev., 88, 499.

Kahneman, D., \& Lovallo, D. (1993). Timid choices and bold forecasts: A cognitive perspective on risk taking. Management Science, 39(1), 17-31.

Kiani, I., Laroche, M., \& Paulin, M. (2016). Development of market Mavenism traits: Antecedents and moderating effects of culture, gender, and personal beliefs. Journal of Business Research, 69(3), 1120-1129.

Kis, A., Hernádi, A., Kanizsár, O., Gácsi, M., \& Topál, J. (2015). Oxytocin induces positive expectations about ambivalent stimuli (cognitive bias) in dogs. Hormones and Behavior, 69, 1-7.

Klein, C. R. (2009). What do we know about interpersonal skills? A meta-analytic examination of antecedents, outcomes, and the efficacy of training. University of Central Florida.

Kogan, A., Saslow, L. R., Impett, E. A., Oveis, C., Keltner, D., \& Saturn, S. R. (2011). Thin-slicing study of the oxytocin receptor (OXTR) gene and the evaluation and expression of the prosocial disposition. Proceedings of the National Academy of Sciences, 108(48), 19189-19192.

Kopalle, P. K., Lehmann, D. R., \& Farley, J. U. (2010). Consumer expectations and culture: The effect of belief in karma in India. Journal of Consumer Research, 37(2), 251-263.

Kulow, K., \& Kramer, T. (2016). In pursuit of good karma: When charitable appeals to do right go wrong. Journal of Consumer Research, 43(2), 334-353.

Lee, K., \& Ashton, M. C. (2004). Psychometric properties of the HEXACO personality inventory. Multivariate Behavioral Research, 39(2), 329-358.

Lefebvre, G., Lebreton, M., Meyniel, F., Bourgeois-Gironde, S., \& Palminteri, S. (2017). Behavioural and neural characterization of optimistic reinforcement learning. Nature Human Behaviour, 1, 0067.

Lim, H. S., Bouchacourt, L., \& Brown-Devlin, N. (2020). Nonprofit organization advertising on social media: The role of personality, advertising appeals, and bandwagon effects. Journal of Consumer Behaviour.

Liu, Z., Xu, Z., Zhou, Z., \& Li, Y. (2019). Buddhist entrepreneurs and new venture performance: The mediating role of entrepreneurial risk-taking. Small Business Economics, 52(3), 713-727.

Mandel, N. (2003). Shifting selves and decision making: The effects of self-construal priming on consumer risk-taking. Journal of Consumer Research, 30(1), 30-40.

Mansbridge, J. (1999). Trust as an altruistic move. Democracy and Trust.

Markey, P. M., \& Markey, C. N. (2006). A spherical conceptualization of personality traits. European Journal of Personality, 20(3), 169.

Marshall, G. N., Wortman, C. B., Kusulas, J. W., Hervig, L. K., \& Vickers Jr., R. R. (1992). Distinguishing optimism from pessimism: Relations to fundamental dimensions of mood and personality. Journal of Personality and Social Psychology, 62(6), 1067.

McDonald, T. P., Poertner, J., \& Pierpont, J. (1999). Predicting caregiver stress: An ecological perspective. American Journal of Orthopsychiatry, 69(1), 100-109.

McElroy, T., Seta, J. J., \& Waring, D. A. (2007). Reflections of the self: How self-esteem determines decision framing and increases risk taking. Journal of Behavioral Decision Making, 20(3), 223-240.

Meertens, R. M., \& Lion, R. (2008). Measuring an Individual's tendency to take risks: The risk propensity scale. Journal of Applied Social Psychology, 38(6), 1506-1520.

Michod, R. E. (1999). Individuality, immortality, and sex. Levels of Selection in Evolution, 66, 53. 
Moll, J., Krueger, F., Zahn, R., Pardini, M., de Oliveira-Souza, R., \& Grafman, J. (2006). Human frontomesolimbic networks guide decisions about charitable donation. Proceedings of the National Academy of Sciences, 103(42), 15623-15628.

Morton, D. L., Watson, A., El-Deredy, W., \& Jones, A. K. (2009). Reproducibility of placebo analgesia: Effect of dispositional optimism. Pain, 146(1-2), 194-198.

O’Doherty, J., Dayan, P., Schultz, J., Deichmann, R., Friston, K., \& Dolan, R. J. (2004). Dissociable roles of ventral and dorsal striatum in instrumental conditioning. Science, 304(5669), 452-454.

Okasha, S. (2005). Multilevel selection and the major transitions in evolution. Philosophy of Science, 72(5), 1013-1025.

Peciña, M., Azhar, H., Love, T. M., Lu, T., Fredrickson, B. L., Stohler, C. S., \& Zubieta, J. K. (2013). Personality trait predictors of placebo analgesia and neurobiological correlates. Neuropsychopharmacology, 38(4), 639-646.

Poulin, M. J., Holman, E. A., \& Buffone, A. (2012). The neurogenetics of nice: Receptor genes for oxytocin and vasopressin interact with threat to predict prosocial behavior. Psychological Science, 23(5), 446-452.

Pressgrove, G., McKeever, B. W., \& Jang, S. M. (2018). What is contagious? Exploring why content goes viral on twitter: A case study of the ALS ice bucket challenge. International Journal of Nonprofit and Voluntary Sector Marketing, 23(1), e1586.

Profili, S., Sammarra, A., \& Innocenti, L. (2016). Can age make a difference? A moderated model of altruistic organizational citizenship behaviour antecedents. International Journal of Business Science \& Applied Management (IJBSAM), 11(1), 18-31.

Randle, M., \& Dolnicar, S. (2009). Not just any volunteers: Segmenting the market to attract the high contributors. Journal of Nonprofit \& Public Sector Marketing, 21(3), 271-282.

Rilling, J. K., Sanfey, A. G., Aronson, J. A., Nystrom, L. E., \& Cohen, J. D. (2004). The neural correlates of theory of mind within interpersonal interactions. Neuroimage, 22(4), 1694-1703.

Robinhood (2021). Our Mission. Retrieved from https://robinhood.com/us/en/support/articles/our-missi on/

Rosenberg, M. J. (1965). When dissonance fails: On eliminating evaluation apprehension from attitude measurement. Journal of Personality and Social Psychology, 1(1), 28.

Rothbaum, F., Weisz, J. R., \& Snyder, S. S. (1982). Changing the world and changing the self: A twoprocess model of perceived control. Journal of Personality and Social Psychology, 42(1), 5.

Rotter, J. B. (1966). Generalized expectancies for internal versus external control of reinforcement. Psychological Monographs: General and Applied, 80(1), 1.

Rupp, C., Kern, S., \& Helmig, B. (2014). Segmenting nonprofit stakeholders to enable successful relationship marketing: A review. International Journal of Nonprofit and Voluntary Sector Marketing, 19(2), 76-91.

Rushton, J. P., Chrisjohn, R. D., \& Fekken, G. C. (1981). The altruistic personality and the self-report altruism scale. Personality and Individual Differences, 2(4), 293-302.

Saphire-Bernstein, S., Way, B. M., Kim, H. S., Sherman, D. K., \& Taylor, S. E. (2011). Oxytocin receptor gene (OXTR) is related to psychological resources. Proceedings of the National Academy of Sciences, 108(37), 15118-15122.

Scheier, M. F., Carver, C. S., \& Bridges, M. W. (1994). Distinguishing optimism from neuroticism (and trait anxiety, self-mastery, and self-esteem): A reevaluation of the life orientation test. Journal of Personality and Social Psychology, 67(6), 1063.

Schott, B. H., Minuzzi, L., Krebs, R. M., Elmenhorst, D., Lang, M., Winz, O. H., et al. (2008). Mesolimbic functional magnetic resonance imaging activations during reward anticipation correlate with reward-related ventral striatal dopamine release. Journal of Neuroscience, 28(52), 14311-14319.

Schwartz, S. H., \& Howard, J. A. (1984). Internalized values as motivators of altruism. In Development and maintenance of prosocial behavior (pp. 229-255). Springer, .

Shah, P. (2012). Toward a neurobiology of unrealistic optimism. Frontiers in Psychology, 3, 344.

Sharot, T., Korn, C. W., \& Dolan, R. J. (2011). How unrealistic optimism is maintained in the face of reality. Nature Neuroscience, 14(11), 1475-1479.

Sharot, T., Guitart-Masip, M., Korn, C. W., Chowdhury, R., \& Dolan, R. J. (2012). How dopamine enhances an optimism bias in humans. Current Biology, 22(16), 1477-1481.

Sharpe, J. P., Martin, N. R., \& Roth, K. A. (2011). Optimism and the big five factors of personality: Beyond neuroticism and extraversion. Personality and Individual Differences, 51(8), 946-951.

Stark, O. (1989). Altruism and the quality of life. The American Economic Review, 79(2), 86-90.

Sussman, R. W., \& Cloninger, C. R. (2011). Origins of altruism and cooperation. Springer. 
Thyne, M. (2001). The importance of values research for nonprofit organisations: The motivation-based values of museum visitors. International Journal of Nonprofit and Voluntary Sector Marketing, 6(2), 116-130.

To, C, Kilduff, G. J., Ordoñez, L., \& Schweitzer, M. E. (2018). Going for it on fourth down: Rivalry increases risk taking, physiological arousal, and promotion focus. Academy of Management Journal, 61(4), 1281-1306.

Tost, H., Kolachana, B., Hakimi, S., Lemaitre, H., Verchinski, B. A., Mattay, V. S., et al. (2010). A common allele in the oxytocin receptor gene (OXTR) impacts prosocial temperament and human hypothalamic-limbic structure and function. Proceedings of the National Academy of Sciences, 107(31), 13936-13941.

Vaidya, M. (2014). Ice bucket challenge cash may help derisk ALS drug research.

Weber, E. U., Blais, A. R., \& Betz, N. E. (2002). A domain-specific risk-attitude scale: Measuring risk perceptions and risk behaviors. Journal of Behavioral Decision Making, 15(4), 263-290.

White, C. J. M. (2017). Belief in karma: The content and correlates of supernatural justice beliefs across cultures. Doctoral dissertation.

White, C. J., \& Norenzayan, A. (2019). Belief in karma: How cultural evolution, cognition, and motivations shape belief in supernatural justice. In Advances in experimental social psychology (Vol. 60, pp. 1-63). Academic Press.

Williams, D. G. (1992). Dispositional optimism, neuroticism, and extraversion. Personality and Individual Differences, 13(4), 475-477.

Wilson, D. S. (1977). Structured demes and the evolution of group-advantageous traits. The American Naturalist, 111(977), 157-185.

Zak, P. J., Stanton, A. A., \& Ahmadi, S. (2007). Oxytocin increases generosity in humans. PLoS One, 2(11), e1128.

Publisher's note Springer Nature remains neutral with regard to jurisdictional claims in published maps and institutional affiliations. 